\title{
CORRECTION TO: COMPARATIVE EVALUATION OF EX SITU AND IN SITU METHOD OF FABRICATING ALUMINUM/TIB 2 COMPOSITES
}

\author{
V. S. Ayar (i) and M. P. Sutaria \\ Department of Mechanical Engineering, Chandubhai S. Patel Institute of Technology, Charotar University of Science and \\ Technology (CHARUSAT), Changa, Anand, Gujarat, India
}

Correction to: International Journal of Metalcasting https://doi.org/10.1007/s40962-02000539-7

In the original version of the article, $\mathrm{AlSi} 5 \mathrm{Cu} 3$ erroreously appeared as $\mathrm{AlSi}_{5} \mathrm{Cu}_{3}$. The original article has been corrected.
Publisher's Note Springer Nature remains neutral with regard to jurisdictional claims in published maps and institutional affiliations. 